\title{
A new pentatomoid bug from the Ypresian of Patagonia, Argentina
}

\author{
Julián F. Petrulevičius \\ Acta Palaeontologica Polonica 61 (4), 2016: 863-868 doi:https://doi.org/10.4202/app.00308.2016
}

A new pentatomoid heteropteran, Chinchekoala qunita gen. et sp. nov. is described from the lower Eocene of Laguna del Hunco, Patagonia, Argentina. The new genus is mainly characterised by cephalic characters such as the mandibular plates surpassing the clypeus and touching each other in dorsal view; head wider than long; and remarkable characters related to the eyes, which are surrounded antero-laterally and posteriorly by the anteocular processes and the pronotum, as well as they extend medially more than usual in the Pentatomoidea. This is the first pentatomoid from the Ypresian of Patagonia and the second from the Eocene in the region, being the unique two fossil pentatomoids in Argentina.

Julián F. Petrulevičius [levicius@fcnym.unlp.edu.ar], CONICET and División Paleozoología Invertebrados, Facultad de Ciencias Naturales y Museo, Universidad Nacional de La Plata, Paseo del Bosque s/n, La Plata 1900, Argentina.

This is an open-access article distributed under the terms of the Creative Commons Attribution License (for details please see creativecommons.org), which permits unrestricted use, distribution, and reproduction in any medium, provided the original author and source are credited. 